\title{
Impact of ISO: 17020 for Quality Assurance System in Construction Sector
}

\author{
Vikas Patel, Brijesh Singh*, P N Ojha, B. Pandu Ranga Rao, Amit Sagar
}

1 National Council for Cement \& Building Materials, Ballabgarh

* Corresponding Author: brijeshsehwagiitr96@gmail.com

Received: 11-08-2021

Accepted: 19-12-2021

\begin{abstract}
The objective of the paper is to analyze the various factors and loop holes that have a significant impact on effectiveness of quality and quality assurance system and to suggest recommendations to increase the quality performance of the construction projects. The paper also highlights the difference in Quality Assurance system of projects wherein ISO: 17020 is not implemented and the project wherein it is implemented. In the current paper, National Council for Cement and Building Materials, India monitored 30 construction projects were selected with a construction cost between five to thirty Crores covering 15 project with ISO:17020 procedures and 15 project without ISO:17020 procedures. The data was collected from these projects on various quality and management related aspects. These projects cover structures such as school buildings, community hall, hostel block, convention centers etc. The study was conducted for construction projects of different government bodies. This analysis has been mainly done covering the factors playing key role in quality of a structure during construction such as client's commitment towards quality, quality of material, documentation, work practices, personnel etc. Based on the data analysis, quality assurance system for these projects were categorized as Excellent, Good, Average and Poor in Quality Grading based on the various factors that directly or indirectly affects the quality and smooth functioning of project during and post construction. The difference in implementation of quality system with and without ISO: 17020 is highlighted in the paper.
\end{abstract}

Key words: ISO: 17020, Quality System, Quality Grading, Construction Industry.

\section{Introduction}

In the era of open economy, quality has emerged as important parameter that determines the success or failure of an organization. Quality, though an elusive attribute, has always been an important issue in construction. It is an integral concept that provides a competitive edge to one organization over the other. The construction industry being unique in nature is always expected to create a balance between cost, time and quality. This has become a critical parameter for Engineering, procurement, construction and commissioning (EPCC) contracts in particular where the agency is responsible for performance of the structure. Quality assurance is needed because of the involvement of negligence and lack of knowledge especially in smaller projects which deduces the quality of the construction. How to establish a quality assurance system and implement the quality assurance system for overall upgrading of the construction quality has become a very essential topic. In order to build customer confidence, the quality of its work should be done according to the developed quality assurance program. Now a days in order to enhance the quality implementation at construction site; laid down standards such as ISO: 17020 accreditation for inspection bodies is the need of hour. The implementation of ISO: 17020 is helping Inspection bodies to gain confidence of the customers on the technical competence and recognition of good management practice.

The Construction industry of India is an important indicator of the development as it creates investment opportunities across various sectors. The industry is fragmented, with a handful of major companies involved in the construction activities across all segments and small and medium contractors who work on the subcontractor basis and carry out the work in the field. Therefore, quality assurance (QA) becomes important due to involvement of large number of 
stakeholders. Quality is one of the critical factors in the success of construction projects. Quality of construction projects, as well as project success, can be regarded as the fulfillment of expectations (i.e. the satisfaction) of the project participants. The construction industry in India has been struggling with quality issues for many years. The construction costs can be significantly reduced if the construction industry embraces the concept of quality assurance and control. Quality Control (QC) is concerned with actual measurement, testing or supervision of manufacturers own final product control, either by inspection of each unit or by sample testing.

It has become more important nowadays to test buildings to assess whether they are performing as expected well before their anticipated service life attributing the failure in quality system. Poor workmanship can lead the construction to an extent that may not meet the requirement of a stable and sustainable infrastructure. The standard of workmanship can be improved by providing adequate training, appropriate instructions and clear checklists as well as ensuring there is on-site supervision and monitoring and an ongoing process of feedback to ensure continuous improvement. Unfortunately, quality control is often forgotten in the rush to complete the project, or sometimes just turns into a paper exercise. However, it must be ensured that the quality control is treated seriously, is not only about paperwork, and that people are delegated with specific responsibilities to deliver the correct quality as poor quality results in:

- Additional costs and delays when work have to be redone.

- Additional costs when defects have to be repaired later, for increased maintenance costs or for disruptions to their operations while defects are repaired.

- Can cause injury and death if the structure fails.

The objective of construction independent quality assurance is to independently assure that the activities of a specific project are being performed in accordance with all contractual specifications, codes and standards or government regulations. The QA/QC is verified through checks audits, inspections and witnessing. These audit services are carried out completely independently of the individual contractors, materials suppliers, manufacturer or sub-contractor as well as final user. Quality Assurance (QA) provides the facility owner with adequate confidence that a structure, component, material or system meets pre-stated quality standards and will perform satisfactory during service. Independent Quality Assurance (IQA) examines whether projects and programmes are on track for successful completion or whether action is required to prevent failure. It can improve the probability of successful project delivery and minimize the risk of cost and time blowouts. An IQA often provides very large returns by preventing costly project mistakes and delivering benefits earlier. An IQA is usually conducted on behalf of the project Sponsor or Executive to provide assurance that the project is appropriately planned, managed and controlled, and that the governance supports the project to best effect. All the quality paperwork in the world, with all their signatures, will not turn a poor quality product into a good quality product. However, the paperwork trail is important in ensuring that proper quality procedures have been implemented and followed.

The process of assuring quality by Independent Quality Assurance will further be improved by the implementation of ISO: 17020 as the overall system of quality system can be improved with the proper acceptance of the guidelines of the ISO: 17020. The requirements of ISO 17020 are contained mainly in 14 major sections including: (i) Administrative requirements, (ii) Requirements for independence, impartiality \& integrity, (iii) Confidentiality, (iv) Organization \& management, (v) Quality system, (vi) Personnel, (vii) Facilities \& equipment, (viii) Inspection methods \& procedures, (ix) Handling of inspection samples \& items, (x) Control of records, (xi) Inspection reports \& inspection certificates, (xii) Subcontracting, (xiii) Complaints \& appeals and (xiv) Cooperation with other inspection bodies. ISO 17020 requires procedures in several important areas, including procedures for performing inspections, performing non-standard inspections, corrective action, inspection of materials received by the organization, appropriate 
storage facilities and protecting the integrity \& ensuring the security of data produced by the organization.

\section{Aim of study}

The objective of the paper is to analyze the various factors that have a significant impact on effectiveness of quality and quality assurance system. The aim here is to put forward various key aspects and challenges encountered in achieving the quality in construction. The paper highlights the impact of implementation of ISO: 17020 in construction system which can contribute to overall up gradation in quality of projects.

\section{Study analysis}

To analyze the quality of the different construction projects, National Council for Cement and Building Materials, India monitored 30 construction projects (15 before implementation of ISO: 17020 and 15 after implementation of ISO: 17020) were selected for Delhi and NCR with a construction cost between three to five Crores and data was collected from these projects on various quality and management related aspects. These 30 projects cover structures such as school buildings, community hall, hostel block, roads, drainage etc. The study was conducted for construction projects of four different government bodies. These projects were assessed for the quality assurance based on the factors playing key role in quality of a structure during construction such as documentation, quality of material, work practices, personnel and client commitment towards quality etc.

\begin{tabular}{|c|c|c|c|c|}
\hline \multicolumn{5}{|c|}{ Factors considered to evaluate the quality of project } \\
\hline$\downarrow$ & $\downarrow$ & $\downarrow$ & $\downarrow$ & $\downarrow$ \\
\hline Documentation & $\begin{array}{l}\text { Quality of } \\
\text { material }\end{array}$ & Work Practices & Personnel & $\begin{array}{c}\text { Client } \\
\text { commitment } \\
\text { towards } \\
\text { quality }\end{array}$ \\
\hline $\begin{array}{c}\text { Approved } \\
\text { structural } \\
\text { drawing }\end{array}$ & $\begin{array}{c}\text { Use of approved } \\
\text { /non- } \\
\text { conforming } \\
\text { material }\end{array}$ & $\begin{array}{l}\text { Pre-calculation } \\
\text { of quantities of } \\
\text { material }\end{array}$ & $\begin{array}{l}\text { Repetition of } \\
\text { common } \\
\text { issues by } \\
\text { workmanship }\end{array}$ & $\begin{array}{c}\text { Availability of } \\
\text { Equipments at } \\
\text { site }\end{array}$ \\
\hline Mix design & $\begin{array}{l}\text { Storage of } \\
\text { material }\end{array}$ & $\begin{array}{l}\text { Concrete Cover } \\
\text { at site } \\
\text { (durability } \\
\text { issue) }\end{array}$ & Shortage of staff & $\begin{array}{l}\text { Action taken } \\
\text { report on Non- } \\
\text { Conformances }\end{array}$ \\
\hline $\begin{array}{c}\text { Source } \\
\text { approval }\end{array}$ & Material testing & $\begin{array}{l}\text { Alignment \& } \\
\text { Quality } \\
\text { of shuttering }\end{array}$ & $\begin{array}{l}\text { Awareness of } \\
\text { latest } \\
\text { standards and } \\
\text { specifications }\end{array}$ & Presence at site \\
\hline $\begin{array}{l}\text { QA/QC System } \\
\text { available }\end{array}$ & Concrete quality & $\begin{array}{c}\text { Reinforcement } \\
\text { detailing }\end{array}$ & & $\begin{array}{c}\text { Timely } \\
\text { intimation for } \\
\text { checking of } \\
\text { major work }\end{array}$ \\
\hline
\end{tabular}

Curing at site 


\subsection{Factors considered}

\subsubsection{Documentation}

Quality records describe the work involved and contain evidence that work items met the requirements of the plans and specifications; sampling and testing personnel, procedures and equipment were properly certified or accredited; and corrective action was taken for any nonconforming conditions. Documents such as Structural drawing, Source approval and Mix design ensure that the construction meets the quality requirement as well as functional requirement post construction. Availability of QA/QC System/Service ensures the Evaluation of overall project performance on a regular basis to provide confidence that the project will satisfy the relevant quality standards. The graph below shows the percentage of the projects that were fulfilling the requirements of the documentation with all the documents duly approved and used during the construction with and without implementation of ISO: 17020.

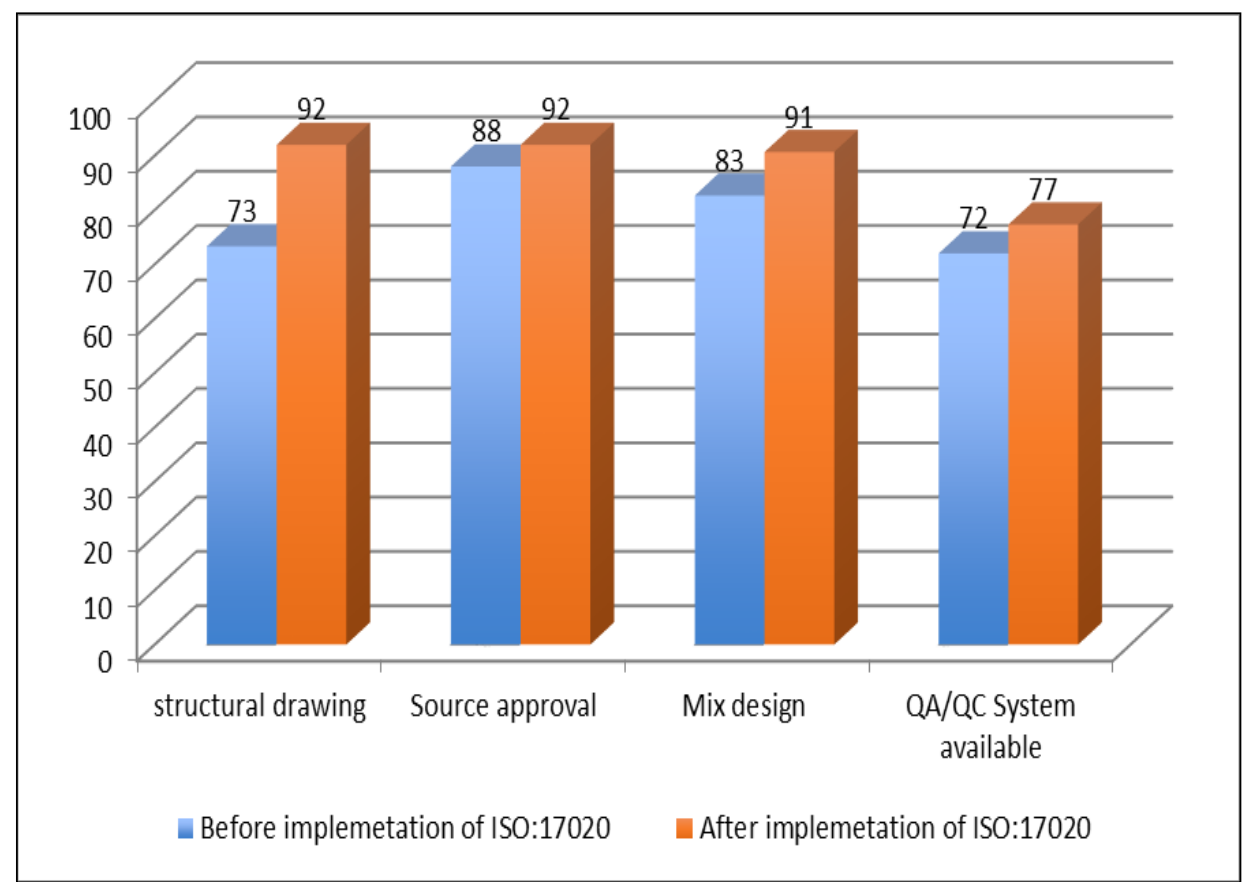

Fig. 1. Graph representing the projects fulfilling documentation requirement

The graph here (Fig. 1) shows that the documentation after implementation of ISO: 17020 has been improved in all respect as while following guidelines of ISO: 17020 these documents becomes must to be complied. Proper documentation can only be achieved if it is strictly compelled as if kept lenient there surely will be negligence. Therefore, ISO: 17020 makes sure that the essential documents like drawings, mix design, etc., are reviewed and records are well maintained to assess the quality of work at any time.

\subsubsection{Quality of material}

To ensure the quality of materials, all the materials should be procured from the approved sources as per the tender documents and the source should not be changed during course of the project. Storage of material (steel, cement, water \& bricks etc.) plays an important role and small negligence will result in reduced quality and increased overall cost of the project. Material testing is one of the major tools with the construction industry to check the quality of materials used in construction. The major part in any construction project includes concrete and hence quality of concrete has direct influence on the overall performance of structure. Taking care of following governing factors can ensure concrete quality: 
- Workability and Control / checks on w/c (water cement ratio)

- Transport and placing time lag, tools used for placement

- Expansion joints type and execution

- Finishing of concrete including placement, compaction

- Provision for maintenance of concrete surface

The graph below shows the percentage of the projects that were fulfilling the requirements of the quality of the material used for the construction including the approved source, proper storage and ensuring timely material testing under quality control with and without implementation of ISO: 17020.

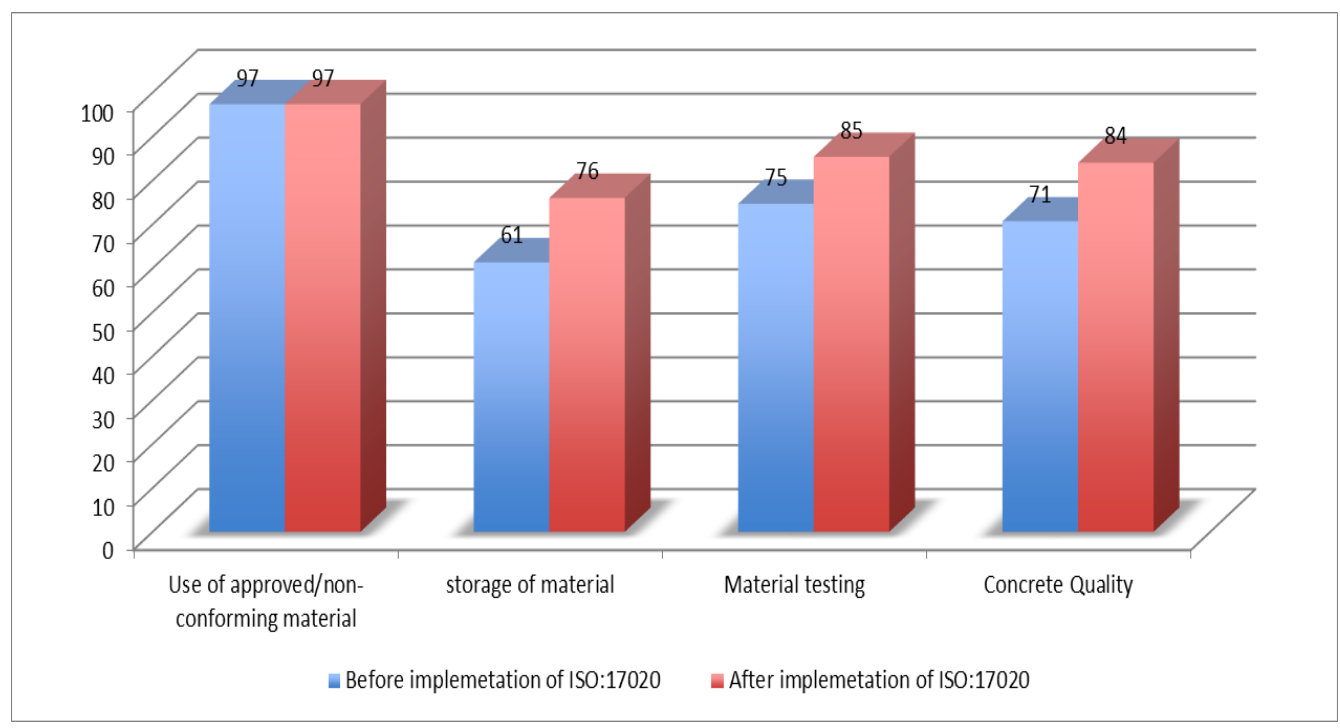

Fig. 2. Graph representing the projects fulfilling the quality of material used

The graph (Fig. 2) shows that the storage of materials was not as per the specifications for many projects which is major point of concern. However, with implementation of ISO: 17020 the percentage of the projects with proper storage of materials, material testing and concrete quality can be observed as improved when compared to when ISO: 17020 was not implemented. Improper storage of materials results in degradation of the even good quality materials. ISO: 17020 provides with checks that ensures the proper storage, testing, handling and quality of the material used for construction. ISO: 17020 not only deals with material but also ensures proper process involved with the use of materials at construction site.

\subsubsection{Work Practices}

Even ensuring the quality of materials will not result in the good quality end product if the construction methods used are not as per the standards. Construction procedures and the technology used have a great influence on the quality, which if not met to the specifications will result in structure that is not safe and sustainable. Some factors that needs to be taken care of during construction includes pre-calculation of quantities of material, durability related issues such as size, grade, spacing of cover blocks at site, alignment \& quality of shuttering and proper reinforcement detailing that can be understood by the site personnels. Since the major part of the structure comprises of concrete along with its quality precautions should be taken during the execution of concreting such as proper transportation, placement, compaction and finally curing once concrete is hardened. The graph below shows the percentage of the projects that were fulfilling the requirements of the work practices by ensuring the correct methods and procedures during the execution of the work with and without implementation of ISO: 17020. 


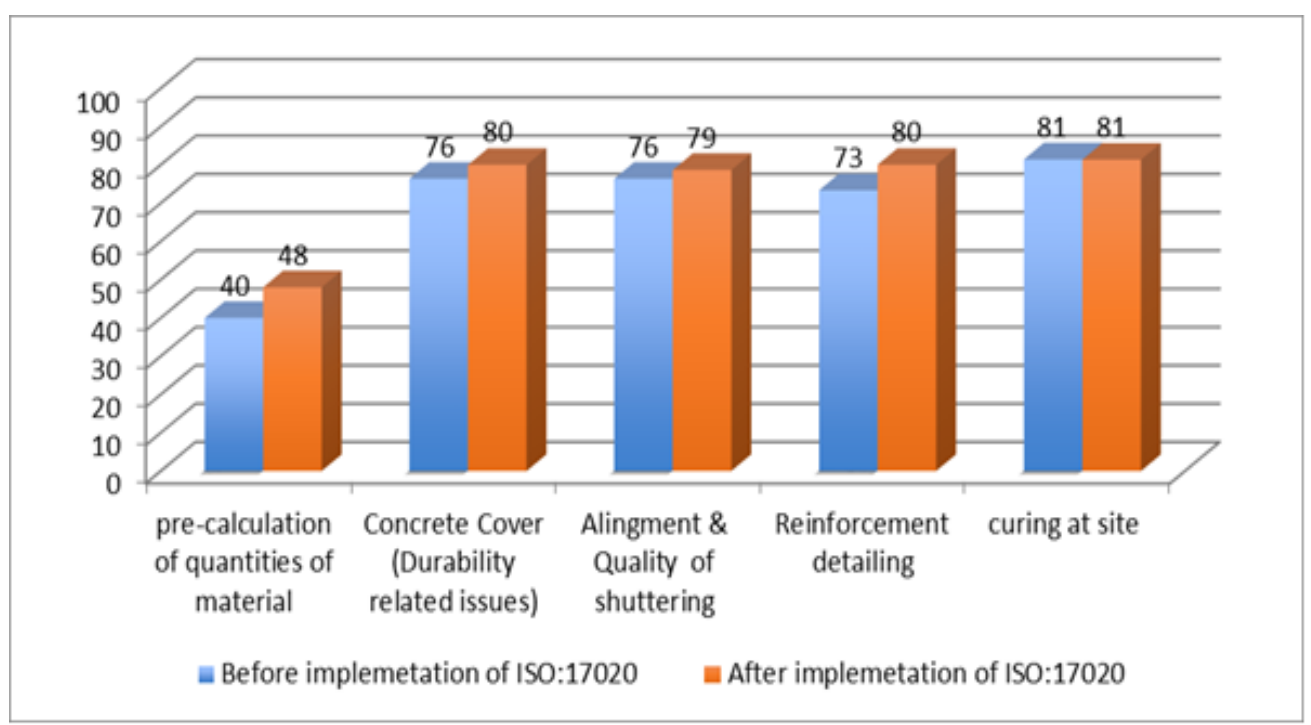

Fig. 3. Graph representing the projects fulfilling the work practices

The above graph (Fig. 3) shows that improvement was there after implementation of ISO:17020, however this improvement was not significant as the factors involved under this section contains various practical constrains which sometimes becomes difficult to take care at site. Their improvement can be achieved in a long run if ISO:17020 is followed as the processes involved and the implications of the processes vary with the officials working, time, place, etc.

\subsubsection{Personnel}

The construction industry is booming and as a result, increase in construction defects is common nowadays. One of the major areas of concern is poor workmanship. In simple terms, workmanship is the skill and quality used in making the product or completing a project. Workmanship is about quality; good or bad. If workers are careless or don't follow proper protocol, then it leads to a finished product that lacks the quality anticipated. The failures of building structures are due to workmanship negligence and the lack of effort put into quality control processes on the construction site. The construction industry, and the professionals at every level are responsible for meeting standards of quality, care, and expertise. Quality work begins with the conscious efforts of contractors to execute the specifications of the contract. Unskilled workman, unsuitable equipment and materials, and lack of project management lead to poor workmanship. Poor workmanship can result in problems such as corrosion, molding, plumbing issues, injuries and death, loss of water through evaporation, cracks in foundation and walls and leaking roofs. The graph below shows the percentage of the projects that were fulfilling the requirements of the good manpower with technical expertise and awareness of latest specifications and technology used in the construction with and without implementation of ISO: 17020 . 


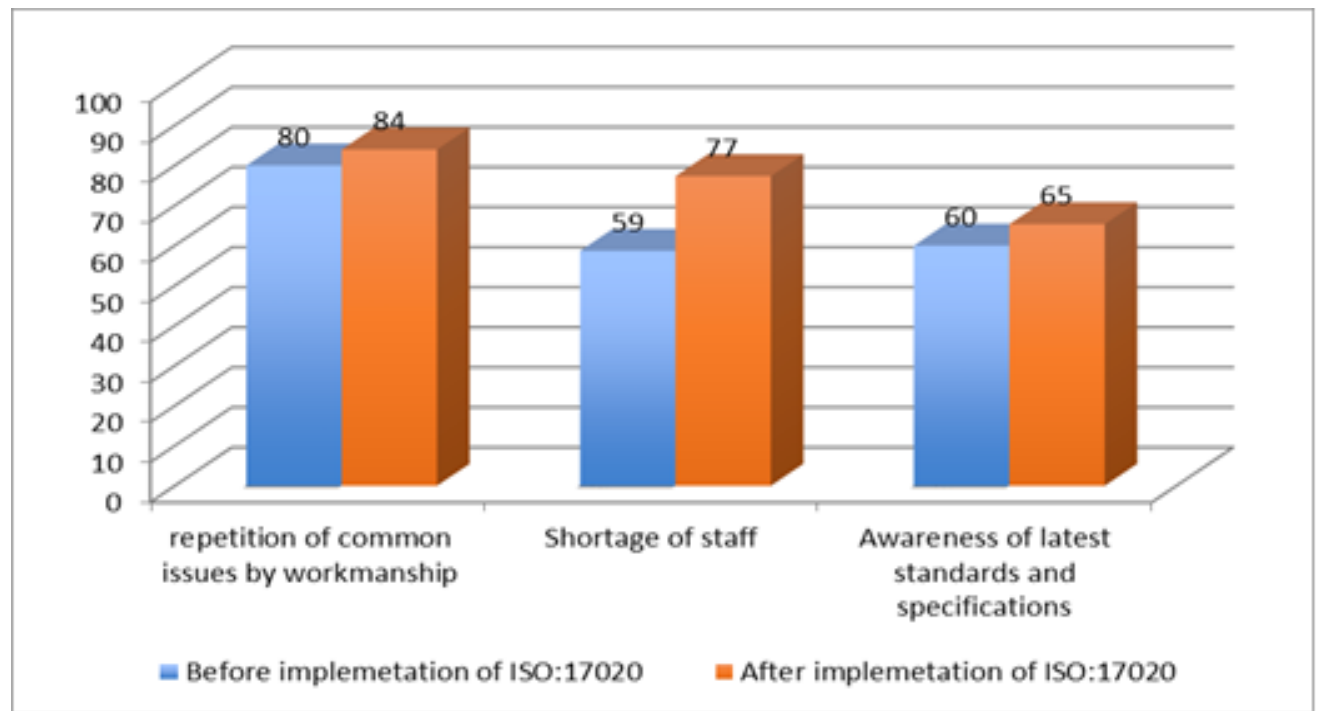

Fig. 4. Graph representing the projects fulfilling the requirement of personnel

The above graph shows that improvement was there after implementation of ISO:17020, however this improvement was not significant as the factors involved under this section attributes to the officials, workers and labors working at site. There major factor that needs to be considered is that the officials, workers, labors needs to be more or less same for particular project during the entire duration of construction. Their improvement can be achieved in a long run if ISO:17020 is followed as the way and the awareness of the right methods, processes and use of materials vary with the officials working, place, etc.

\subsubsection{Client commitment towards quality}

Client's attitude towards the project shapes the progress and quality of the project. Presence of client's representative at site ensures the proper workmanship and work practices used in construction. Major problem with the projects is availability of equipments at site that results in improper construction practices. Client can play an important role by ensuring that the action is taken on the non-conformances reported and by timely intimating the checking of major work to the independent quality assurance agency. The graph below shows the percentage of the projects where client's commitment towards the quality was upto the mark.

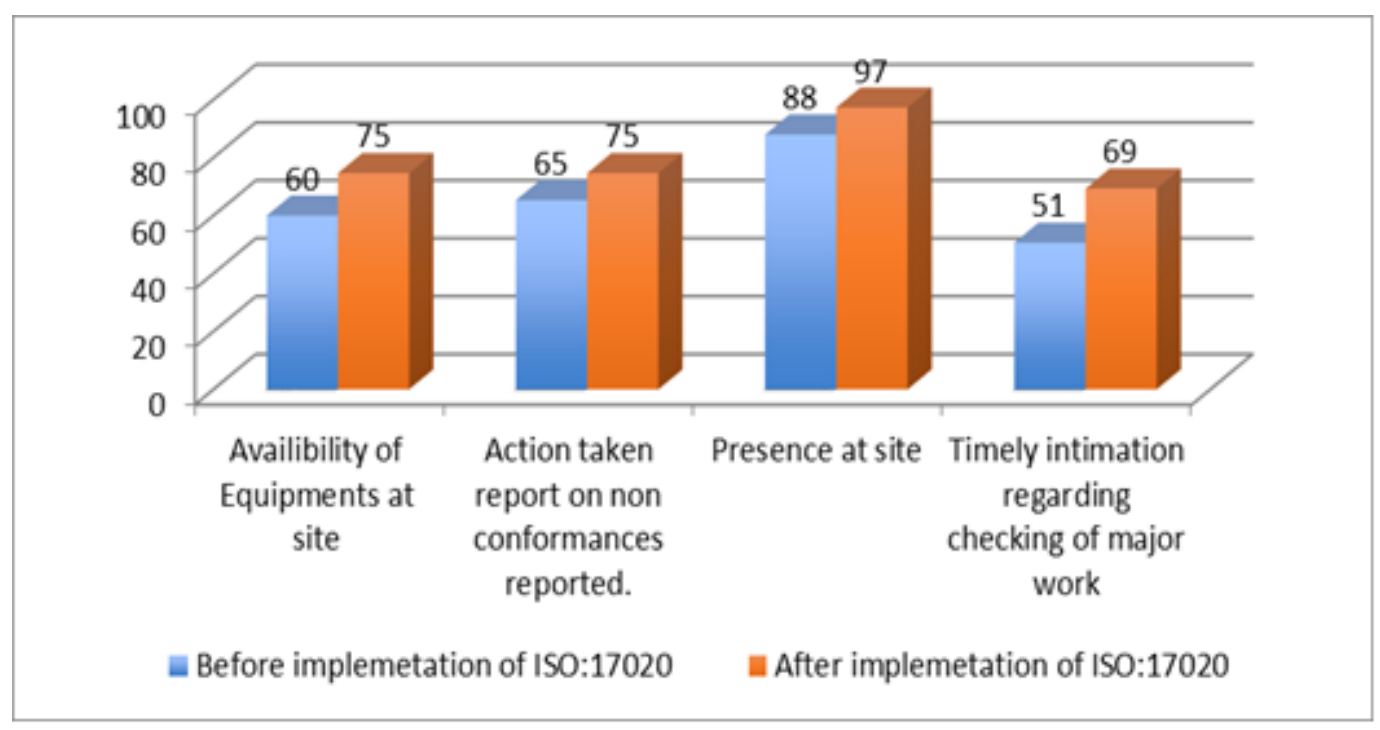

Fig. 5. Graph representing the projects where quality was ensured by client 
The above graph shows that improvement was there after implementation of ISO: 17020, however the significant improvement was not observed which can be attributed to fact that ISO: 17020 provides the guidelines for the improvement of the quantifiable factors and client's commitment is to be morally developed on itself. However, ISO:17020 helps in achieving that as some factors like availability of equipment's, presence at site, etc., are ensured under its guidelines.

\section{Quality Grading of the Quality Assurance System for projects studied}

Each factor mentioned above was given weightage (1 to 3 ) based upon its relative importance towards the quality of the project and was rated on a scale from 2 to 5 based on the inspections and analyzing the data from the projects. Based on the ratings obtained by the project, it can be classified under following categories:

\begin{tabular}{|c|c|}
\hline $\begin{array}{c}\text { Category/Range } \\
\text { of Rating }\end{array}$ & Conformances to the factors considered \\
\hline Excellent $(>85 \%)$ & All major and minor factors conforming. \\
\hline Good $(70-85 \%)$ & $\begin{array}{c}\text { All the major factors conforming and few nonconformances related to } \\
\text { the minor factors such as source approval, pre-calculation of quantities } \\
\text { of materials and presence of client at site. }\end{array}$ \\
\hline $\begin{array}{c}\text { Average }(60- \\
70 \%)\end{array}$ & $\begin{array}{c}\text { Few non conformances to major and minor factors considered such as } \\
\text { durability, availability of equipments at site, line \& levels and alignment } \\
\text { \& quality of shuttering. }\end{array}$ \\
\hline Poor $(<60 \%)$ & $\begin{array}{c}\text { Non conformances for the major factors considered such as structural } \\
\text { drawings, material testing, concrete quality, durability, training of staff, } \\
\text { awareness to latest standard and specifications. }\end{array}$ \\
\hline
\end{tabular}

\begin{tabular}{|c|c|c|c|}
\hline \multirow{2}{*}{ Category } & Range of Rating & $\begin{array}{c}\text { Nefore implementation } \\
\text { of ISO:17020 }\end{array}$ & $\begin{array}{c}\text { After implementation } \\
\text { of ISO:17020 }\end{array}$ \\
\cline { 3 - 4 } & $>85 \%$ & 0 & 6 \\
\hline Excellent & $70-85 \%$ & 11 & 9 \\
\hline Good & $60-70 \%$ & 3 & 0 \\
\hline Average & $<60 \%$ & 1 & 0 \\
\hline Poor & $<$ & & 0 \\
\hline
\end{tabular}

Before implementation of ISO:17020

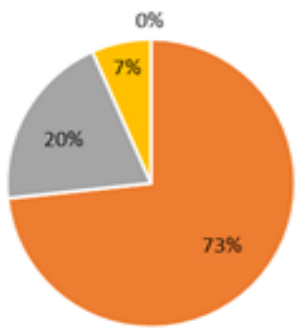

- Excellent $>85 \%$. Good $70854 \%$ Average 6070\% * P0or $460 \%$
After implementation of ISO:17020

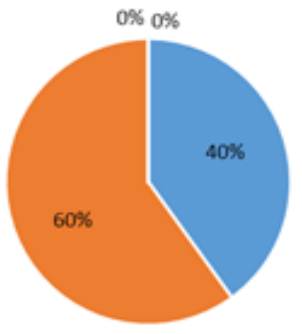

- Excellent $>85 \%$ = Good 70-85\% - Average 60-700\% = Poor $<60 \%$

Fig. 6. Pie Chart indicating Quality Grading of Quality Assurance System for Projects Studied based on detail study given in Table as appendix $1 \& 2$ 


\section{Conclusion}

The grading distribution obtained for Quality Assurance System of the projects shows that the most of the projects were categorized under good and average category before implementation of ISO: 17020 while after implementation of ISO: 17020 all the projects were under excellent and good category. The major negligence found were with storage of materials, work practices used during construction, availability of equipment's at the site and negligence by the personnel working at site which should be improved in order to attain the desired quality and service life of finished infrastructures. Quality is an essential element for sustainability and consumer satisfaction. It is very important to achieve the quality of the finished product in the construction industry. The high cost of the infrastructures makes it necessary to ensure the quality of the finished structure. Therefore, a system with proper guidelines to achieve the desired quality should be available and followed at best to have enhanced overall quality of the structure. ISO: 17020 specifies the various guidelines to make the quality assurance system more systematic and effective. Effective quality assurance system will not only enhanced quality but will rather help in achieving the more sustainable and efficient infrastructure along with optimum usage of resources.

Based on the study done, it can be inferred that implementation of ISO: 17020 has definitely helped in improving the quality system at site and will definitely further improve the quality system which ultimately will lead enhanced service life of structure.

\section{References}

Vikas Patel, Mohd. Ali Saifi, B. Pandu Ranga Rao, Brijesh Singh \& Pritam Rawat (2017) "Independent Quality Assurance Monitoring System in Construction-A Case Study for Delhi" 15th NCB Seminar 2017

IRC SP $47-1998$

Abdol R. Chini. \& Hector E Valdez. (2013) “ISO 9000 and the U.S. Construction Industry” J. Manager Eng. 19 (2).

Arditi D. \& Gunaydin H.M. (1997) "Total quality management in the Construction process" J. International journal of project management 15(4)

State of California Department of Transportation Construction, Quality Assurance Program Manual.

Teena Joy (2014), “A Study on Factors Influencing Quality of Construction Projects", International Journal of Innovative Research and Development, 2278-0211.

ASTM, (2007). ASTM international standards worldwide.

Ammad Hassan Khan, Salman Azhar, Arshad Mahmood (2008) "Quality Assurance and Control in the Construction of Infrastructure Services in Developing Countries - A Case Study of Pakistan", First International Conference on Construction in Developing Countries (ICCIDC-I).

Griffith, A (1990). "Quality assurance in building” Macmillan Education. 


\begin{tabular}{|c|c|c|c|c|c|c|c|c|c|c|c|c|c|c|c|c|c|c|}
\hline & S. No. & Factors Considered & Weightage & P16 & P17 & P18 & P19 & P20 & P21 & P22 & P23 & P24 & P25 & P26 & P27 & P28 & P29 & P30 \\
\hline \multirow{4}{*}{$\begin{array}{c}\text { Client's } \\
\text { commitment } \\
\text { towards quality }\end{array}$} & 1 & Availibility of Equipments at site & 3 & 3 & 3 & 3 & 3 & 3 & 3 & 3 & 3 & 3 & 3 & 3 & 3 & 3 & 3 & 3 \\
\hline & 2 & $\begin{array}{l}\text { Action taken report on non } \\
\text { conformances reported. }\end{array}$ & 2 & 4 & 3 & 3 & 3 & 3 & 3 & 3 & 3 & 3 & 3 & 3 & 3 & 3 & 5 & 4 \\
\hline & 3 & Presence at site & 1 & 5 & 5 & 4 & 4 & 4 & 4 & 4 & 5 & 5 & 4 & 5 & 4 & 4 & 4 & 5 \\
\hline & 4 & $\begin{array}{l}\text { Timely intimation regarding } \\
\text { checking of major work }\end{array}$ & 2 & 2 & 2 & 3 & 3 & 3 & 3 & 3 & 3 & 2 & 2 & 2 & 3 & 3 & 2 & 2 \\
\hline \multirow{4}{*}{ Quality of material } & 5 & $\begin{array}{l}\text { Use of approved material as } \\
\text { per the tender documents }\end{array}$ & 2 & 5 & 5 & 5 & 5 & 5 & 5 & 5 & 4 & 5 & 5 & 5 & 5 & 4 & 5 & 5 \\
\hline & 6 & $\begin{array}{l}\text { storage of material (steel, } \\
\text { cement,water \& bricks etc.) }\end{array}$ & 2 & 3 & 3 & 3 & 4 & 3 & 3 & 3 & 3 & 3 & 3 & 3 & 3 & 3 & 3 & 3 \\
\hline & 7 & Material testing & 3 & 4 & 5 & 4 & 3 & 3 & 3 & 4 & 4 & 3 & 4 & 4 & 4 & 4 & 4 & 3 \\
\hline & 8 & Concrete Quality & 3 & 4 & 4 & 4 & & 4 & 4 & 5 & 4 & 4 & 4 & 4 & 3 & 3 & 3 & 3 \\
\hline \multirow{4}{*}{ Documentation } & 9 & Approved structural drawing & 3 & 5 & 2 & 3 & 3 & 4 & 3 & 4 & 3 & 2 & 4 & 3 & 4 & 5 & 5 & 5 \\
\hline & 10 & Source approval & 1 & 4 & 5 & 5 & 4 & 4 & 4 & 5 & 4 & 4 & 5 & 5 & 4 & 4 & 5 & 4 \\
\hline & 11 & Mix design & 2 & 5 & 5 & 5 & & 4 & 4 & 5 & 3 & 4 & 5 & 4 & 4 & 4 & 5 & 5 \\
\hline & 12 & QA/QC System available & 2 & 4 & 4 & 4 & 4 & 3 & 3 & 4 & 3 & 4 & 4 & 3 & 4 & 3 & 3 & 4 \\
\hline \multirow{5}{*}{ Work Practices } & 13 & $\begin{array}{l}\text { precalculation of quantities } \\
\text { of material }\end{array}$ & 1 & 2 & 2 & 2 & 2 & 2 & 2 & 2 & 2 & 2 & 2 & 2 & 2 & 2 & 2 & 2 \\
\hline & 14 & $\begin{array}{l}\text { Durability related issues such as } \\
\text { size, grade, spacing of cover at site }\end{array}$ & 3 & 3 & NA & NA & NA & 4 & 3 & 5 & 4 & NA & 4 & 4 & 3 & 4 & 4 & 4 \\
\hline & 15 & $\begin{array}{l}\text { Alingment \& Quality of } \\
\text { shuttering }\end{array}$ & 2 & 3 & NA & NA & NA & 4 & 4 & 4 & 4 & NA & 4 & 4 & 3 & 4 & 4 & 4 \\
\hline & 16 & Reinforcement detailing & 3 & 3 & NA & NA & NA & 5 & 4 & 4 & 4 & NA & 4 & 4 & 4 & 4 & 4 & 4 \\
\hline & 17 & curing at site & 3 & 4 & 4 & 4 & NA & 5 & 4 & 5 & 4 & 4 & 4 & 4 & 3 & 4 & 4 & 4 \\
\hline \multirow{6}{*}{ Personnel } & 18 & $\begin{array}{l}\text { repetition of common issues by } \\
\text { workmanship }\end{array}$ & 1 & 4 & 4 & 4 & 4 & 4 & 4 & 4 & 4 & 4 & 4 & 4 & 4 & 4 & 4 & 4 \\
\hline & 19 & Shortage of staff & 2 & 2 & 3 & 3 & 3 & 3 & 3 & 3 & 3 & 3 & 3 & 3 & 3 & 3 & 3 & 3 \\
\hline & 20 & $\begin{array}{l}\text { Awareness of latest standards and } \\
\text { specifications }\end{array}$ & 2 & 3 & 3 & 3 & 3 & 3 & 3 & 3 & 3 & 3 & 3 & 3 & 3 & 3 & 3 & 3 \\
\hline & & & & 155 & 126 & 127 & 91 & 160 & 148 & 171 & 151 & 117 & 160 & 154 & 148 & 155 & 162 & 159 \\
\hline & & Total (Maximum) & & 215 & 175 & 175 & 160 & 215 & 215 & 215 & 215 & 175 & 215 & 215 & 215 & 215 & 215 & 215 \\
\hline & & Percentage & & 72.09 & 72.00 & 72.57 & 56.88 & 74.42 & 68.84 & 79.53 & 70.23 & 66.86 & 74.42 & 71.63 & 68.84 & 72.09 & 75.35 & 73.95 \\
\hline
\end{tabular}




\begin{tabular}{|c|c|c|c|c|c|c|c|c|c|c|c|c|c|c|c|c|c|c|}
\hline & S. No. & Factors Considered & Weightage & P1 & P2 & P3 & P4 & P5 & P6 & P7 & P8 & P9 & P10 & P11 & P12 & P13 & P14 & P15 \\
\hline \multirow{4}{*}{$\begin{array}{c}\text { Client's } \\
\text { commitment } \\
\text { towards quality }\end{array}$} & 1 & Availibility of Equipments at site & 3 & 5 & 5 & 3 & 4 & 5 & 5 & 3 & 2 & 3 & 3 & 2 & 4 & 4 & 4 & 4 \\
\hline & 2 & $\begin{array}{l}\text { Action taken report on non } \\
\text { conformances reported. }\end{array}$ & 2 & 5 & 5 & 2 & 5 & 4 & 4 & 3 & 3 & 2 & 2 & 2 & 5 & 5 & 4 & 5 \\
\hline & 3 & Presence at site & 1 & 5 & 5 & 4 & 5 & 5 & 5 & 4 & 5 & 5 & 5 & 5 & 5 & 5 & 5 & 5 \\
\hline & 4 & $\begin{array}{l}\text { Timely intimation regarding } \\
\text { checking of major work }\end{array}$ & 2 & 3 & 4 & 2 & 3 & 4 & 3 & 3 & 4 & 3 & 4 & 4 & 4 & 4 & 3 & 4 \\
\hline \multirow{4}{*}{ Quality of material } & 5 & $\begin{array}{l}\text { Use of approved material as } \\
\text { per the tender documents }\end{array}$ & 2 & 5 & 5 & 5 & 5 & 5 & 4 & 5 & 4 & 5 & 5 & 5 & 5 & 5 & 5 & 5 \\
\hline & 6 & $\begin{array}{l}\text { storage of material (steel, } \\
\text { cement,water \& bricks etc.) }\end{array}$ & 2 & 4 & 4 & 4 & 4 & 5 & 3 & 4 & 3 & 4 & 4 & 3 & 4 & 4 & 3 & 4 \\
\hline & 7 & Material testing & 3 & 5 & 5 & 4 & 4 & 5 & 4 & 3 & 3 & 4 & 4 & 4 & 5 & 5 & 5 & 4 \\
\hline & 8 & Concrete Quality & 3 & 4 & 5 & 4 & 4 & 5 & 3 & 4 & 3 & 4 & 4 & 4 & 4 & 5 & 5 & 5 \\
\hline \multirow{4}{*}{ Documentation } & 9 & Approved structural drawing & 3 & 5 & 5 & 5 & 4 & 5 & 4 & 4 & 5 & 4 & 4 & 4 & 5 & 5 & 5 & 5 \\
\hline & 10 & Source approval & 1 & 5 & 5 & 4 & 5 & 5 & 4 & 4 & 5 & 4 & 4 & 4 & 5 & 5 & 5 & 5 \\
\hline & 11 & Mix design & 2 & 5 & 4 & 5 & 5 & 5 & 5 & 5 & 5 & 3 & 3 & 3 & 5 & 5 & 5 & 5 \\
\hline & 12 & QA/QC System available & 2 & 4 & 4 & 3 & 4 & 4 & 4 & 4 & 4 & 3 & 3 & 3 & 5 & 5 & 4 & 4 \\
\hline \multirow{5}{*}{ Work Practices } & 13 & $\begin{array}{l}\text { precalculation of quantities } \\
\text { of material }\end{array}$ & 1 & 2 & 2 & 2 & 2 & 2 & 2 & 2 & 2 & 2 & 2 & 2 & 4 & 4 & 2 & 4 \\
\hline & 14 & $\begin{array}{l}\text { Durability related issues such as } \\
\text { size, grade, spacing of cover at site }\end{array}$ & 3 & 4 & 4 & 3 & 4 & 5 & 4 & 3 & 3 & 4 & 4 & 4 & 5 & 5 & 4 & 4 \\
\hline & 15 & $\begin{array}{l}\text { Alingment \& Quality of } \\
\text { shuttering }\end{array}$ & 2 & 5 & 4 & 4 & 4 & 5 & 3 & 3 & 4 & 4 & 3 & 4 & 4 & 4 & 4 & 4 \\
\hline & 16 & Reinforcement detailing & 3 & 4 & 4 & 5 & 5 & 5 & 4 & 4 & 3 & 4 & 3 & 4 & 4 & 4 & 4 & 3 \\
\hline & 17 & curing at site & 3 & 5 & 5 & 4 & 4 & 5 & 3 & 3 & 4 & 4 & 4 & 4 & 4 & 4 & 4 & 4 \\
\hline \multirow{6}{*}{ Personnel } & 18 & $\begin{array}{l}\text { repetition of common issues by } \\
\text { workmanship }\end{array}$ & 1 & 4 & 4 & 4 & 4 & 5 & 4 & 4 & 4 & 4 & 4 & 4 & 5 & 5 & 4 & 4 \\
\hline & 19 & Shortage of staff & 2 & 4 & 3 & 3 & 3 & 4 & 3 & 3 & 4 & 4 & 4 & 4 & 5 & 5 & 4 & 5 \\
\hline & 20 & $\begin{array}{l}\text { Awareness of latest standards and } \\
\text { specifications }\end{array}$ & 2 & 3 & 3 & 3 & 3 & 4 & 3 & 3 & 3 & 3 & 3 & 4 & 4 & 4 & 3 & 3 \\
\hline & & & & 188 & 187 & 160 & 175 & 202 & 160 & 152 & 153 & 158 & 155 & 157 & 194 & 197 & 179 & 183 \\
\hline & & \begin{tabular}{|l} 
Total (Maximum) \\
\end{tabular} & & 215 & 215 & 215 & 215 & 215 & 215 & 215 & 215 & 215 & 215 & 215 & 215 & 215 & 215 & 215 \\
\hline & & Percentage & & 87.44 & 86.98 & 74.42 & 81.40 & 93.95 & 74.42 & 70.70 & 71.16 & 73.49 & 72.09 & 73.02 & 90.23 & 91.63 & 83.26 & 85.12 \\
\hline
\end{tabular}

